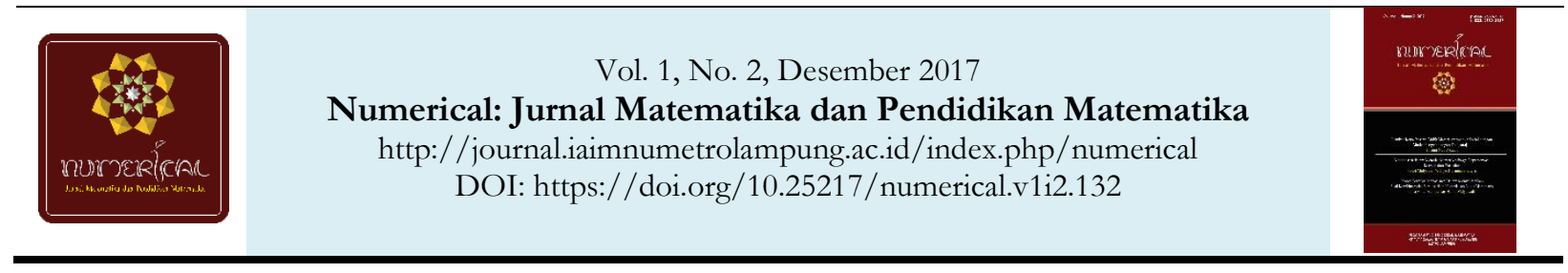

\title{
Lembar Kerja Peserta Didik Materi Aritmatika Sosial dengan Model Pengembangan Thiagarajan
}

\author{
Isnaini Nur Azizah ${ }^{1}$
}

1) Institut Agama Islam Ma'arif NU (IAIMNU) Metro, Indonesia

Correspondence: $\triangle$ zelullaby_a@yahoo.com

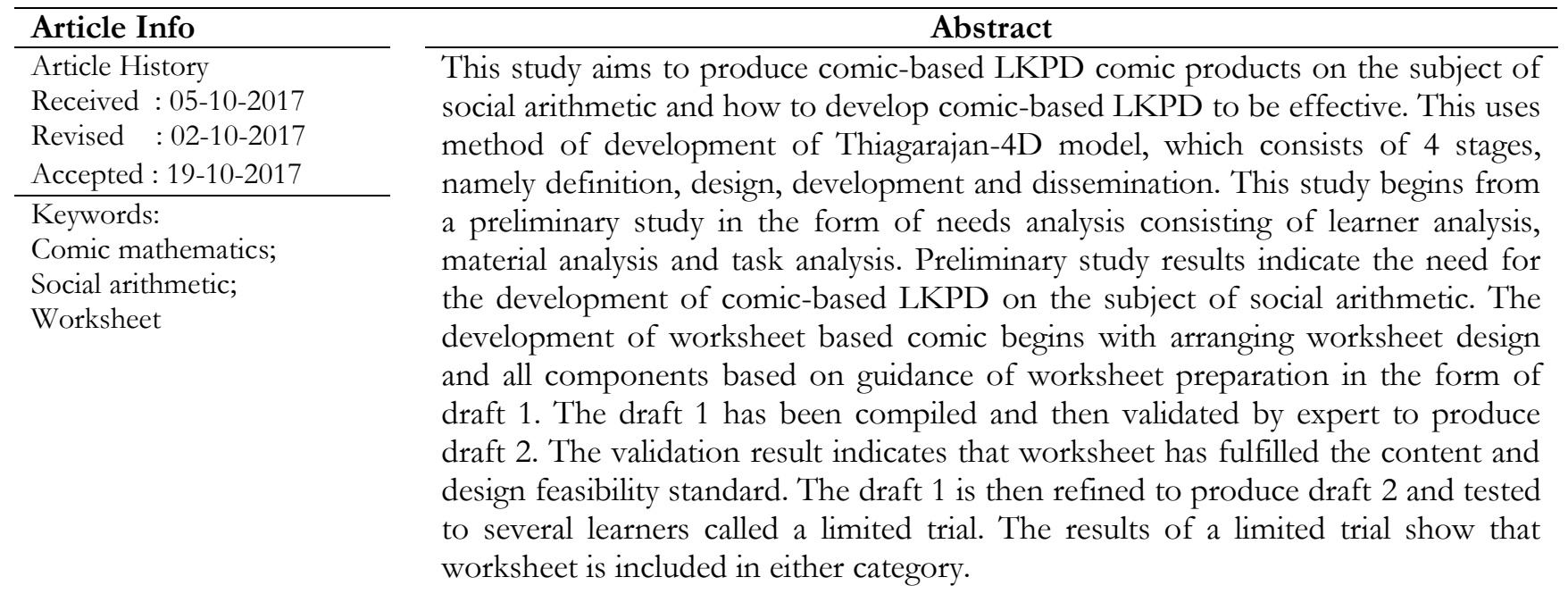

\section{PENDAHULUAN}

Lembar Kerja Peserta Didik (LKPD) merupakan salah satu sumber belajar yang dapat dikembangkan oleh pendidik sebagai fasilitator dalam kegiatan pembelajaran [1]. LKPD adalah lembaran-lembaran berisi tugas yang harus dikerjakan oleh peserta didik [2]. Lembar kegiatan biasanya berupa petunjuk, langkah-langkah untuk menyelesaikan suatu tugas. LKPD berperan penting dalam memberikan berbagai penugasan yang relevan dengan materi yang diajarkan [3]. Prastowo mengemukakan fungsi LKPD sebagai panduan belajar yang memudahkan peserta didik dan guru melakukan pembelajaran sehingga terbentuk interaksi yang efektif antara peserta didik dengan pendidik. LKPD sebagai salah satu perangkat pembelajaran yang umum digunakan sebagai sumber belajar idealnya disusun dan dirancang serta dikembangkan sendiri oleh guru sesuai dengan kondisi dan situasi kegiatan pembelajaran yang dihadapi [4]. Untuk mencapai tujuan pembelajaran dengan baik, pemerintah telah melakukan berbagai usaha dan perbaikan kurikulum [5]. Kementrian Pendidikan dan Kebudayaan (Kemendikbud) telah mengeluarkan aturan baru mengenai pengadaan buku pelajaran yang direkomendasikan bagi pihak sekolah. Aturan tersebut berkaitan dengan penggunaan LKS (sebutan lain dari LKPD) siap pakai yang telah disusun oleh beberapa penerbit. Aturan tercantum dalam Permendikbud Nomor 8 tahun 2016 tentang buku yang digunakan oleh satuan pendidikan [6]. Dengan adanya aturan tersebut penggunaan LKPD siap pakai tidak perlu lagi karena seharusnya LKPD disusun oleh guru agar dapat disesuaikan dengan karakter peserta didik dan materi yang diajarkan. Fakta 
menunjukkan bahwa guru masih banyak yang menggunakan LKPD siap pakai dan enggan untuk menyusun sendiri. Berdasarkan hasil observasi awal diperoleh 63\% MTs di Kota Metro menggunakan LKPD yang siap pakai bahkan mempunyai kemiripan baik isi, penyusunan dan latihan. LKPD berisi ringkasan materi, contoh soal dan soal-soal latihan.

Hasil observasi di SMPN 9 Metro menunjukkan bahwa peserta didik memperoleh materi dari buku atau LKPD cetakan penerbit yang kurang memiliki keterkaitan dengan masalah nyata yang dihadapi peserta didik SMPN 9 Metro [7]. Selain itu, menurut peserta didik LKPD kurang menarik sehingga peserta didik sulit memahami materi. Tidak heran jika peserta didik saat ini lebih gemar membaca buku fiksi (komik dan novel) dibandingkan dengan buku pelajaran. Bahkan komik sebagai salah satu karya fiksi mempunyai andil dalam pembentukan diri anak dan secara tidak langsung ikut mempengaruhi emosi serta rasa simpati anak [8]. Selanjutnya pembelajaran matematika perlu dirancang secara kreatif dan inovatif [9].

Keberadaan komik banyak digunakan hanya sebagai sarana hiburan bagi anak-anak dan remaja. Bacaan yang terdapat pada komik banyak digemari karena gambar dalam komik menyajikan peristiwa dan latar belakang secara jelas, dinamis dan hidup [10]. Hal inilah yang memunculkan pemikiran bahwa komik dapat dijadikan sebagai sumber belajar jika dirancang dan disusun secara sistematis.

Komik bersifat sederhana, menarik dan mudah digunakan serta dapat dipelajari secara mandiri dan berulang-ulang oleh peserta didik. Kelebihan komik yaitu 1) kemampuan komik dalam menciptakan ketertarikan peserta didik; 2) penjelasan materi menjadi lebih menarik; 3) membantu peserta didik dalam memahami konsep yang bersifat abstrak; 4) jalan cerita komik menuju pada kebaikan (pesan moral) dan studi lain [11].

Komik dalam pembelajaran matematika berfungsi sebagai alat yang memperjelas materi, menciptakan nilai rasa lebih dalam memahami materi, menarik minat dan perhatian peserta didik, peserta didik merasa senang, membangkitkan rasa ingin tahu peserta didik, momotivasi peserta didik untuk belajar [12]. Hasil penelitian sebelumnya tentang pengembangan mathematical comic dengan metode PQ4R untuk mengembangkan komunikasi dan disposisi matematika siswa diperoleh indikator komunikasi dengan pencapaian tertinggi yaitu menulis (writing) sedangkan indikator terendah adalah ekspresi matematika (expression mathematic). Pada aspek disposisi matematika diperoleh indikator tertinggi yaitu reflektif, sedangkan indikator terendah adalah percaya diri [10].

Pengembangan LKPD berbasis komik diharapkan dapat menjadi alternatif bagi peserta didik yang membutuhkan sumber belajar yang menarik, tidak membosankan, dan alur cerita yang menuntun siswa untuk terus membaca. Harapannya siswa yang sebelumnya belum tertarik untuk membaca bahan ajar, dengan adanya komik akan lebih tertarik untuk membaca.

Aritmatika sosial adalah salah satu materi yang diajarkan pada jenjang sekolah menengah pada kelas VII semester genap. Materi aritmatika sosial dipilih karena anggapan bahwa materi aritmatika sosial dapat disajikan dalam bentuk cerita yang dapat disesuaikan dengan karakteristik siswa sekolah. Keunggulan produk dalam penelitian ini bahwa LKPD berbasis komik yang dikembangkan mengacu pada metode Contectual Teaching Learning (CTL) sebagai metode dalam memaparkan LKPD berbasis komik.

\section{METODE}

Penelitian ini adalah penelitian dan pengembangan (research \& development) dengan tujuan untuk mengembangkan LKPD berbasis komik pada pokok bahasan aritmatika sosial. Research \& development 
adalah metode penelitian yang digunakan untuk menghasilkan produk tertentu dan menguji keefektifan produk tersebut [13].

Metode pengembangan yang digunakan mengacu pada model-4D [14] yang terdiri atas 4 tahap, yaitu define, design, develop dan desseminate dan diadaptasikan menjadi Model 4-P, yaitu pendefinisian, perancangan, pengembangan dan penyebaran [15]. Pada tahap pendefinisian langkah pertama yang dilakukan adalah analisis kebutuhan. Analisis kebutuhan meliputi tiga aspek yaitu analisis peserta didik, analisis materi dan analisis tugas. Analisis peserta didik bertujuan untuk menelaah karakteristik peserta didik. Adapun karakteristik yang digunakan untuk penelitian ini meliputi kemampuan akademik dan tingkat perkembangan kognitif peserta didik serta lingkungan hidup peserta didik.

Analisis materi bertujuan untuk mengidentifikasi, merinci, dan menyusun secara sistematis konsep-konsep dan keterampilan yang harus diperoleh peserta didik pada pokok bahasan aritmatika sosial. Konsep disusun sedemikian rupa sehingga tampak urutan pembelajaran sesuai dengan RPP. Konsep ini juga nantinya yang membantu peserta didik untuk mencapai tujuan dari pembelajaran. Analisis tugas bertujuan untuk mengumpulkan prosedural terhadap pembelajaran. Analisis tugas merupakan dasar untuk merumuskan tujuan pembelajaran dan merinci isi materi secara garis besar. Adapun analisis tugas meliputi analisis struktur isi, analisis prosedural, dan perumusan tujuan. Analisis ini dilakukan agar tampak struktur isi materi yang ingin disampaikan dalam LKPD. Sesuai dengan urutan konsep yang telah dibuat, maka isi materi LKPD harus disusun menyesuaikan urutan konsep. Data yang diperoleh pada analisis konsep dan bentuk tugas yang diberikan kepada peserta didik kemudian dirumuskan dalam bentuk LKPD yang akan dikembangkan.

Tahap perancangan (design) berdasarkan data yang diperoleh pada tahap pendefinisian, maka disusunlah LKPD berbasis komik. Ada beberapa tahap dalam menyusun LKPD, pertama, merumuskan Kompetensi Dasar (KD) yaitu menggunakan konsep aljabar dalam menyelesaikan masalah aritmatika sosial sederhana. kedua, menentukan alat penilaian. Alat penilaian yang sesuai adalah penilaian formatif, yakni penilaian yang dilaksanakan pada akhir pembelajaran. Penilaian ini digunakan untuk melihat tingkat keberhasilan kegiatan pembelajaran.

Ketiga, menyusun materi. Penyusunan materi LKPD perlu memperhatikan beberapa hal berikut. a) Kompetensi dasar yang akan dicapai, b) informasi pendukung seperti kartun-kartun yang sesuai dengan kehidupan nyata, c) sumber materi seperti dari buku pegangan peserta didik dan pengalaman dalam kehidupan sehari-hari, d) pemilihan kalimat yang jelas sesuai dengan kaidah yang baik dan benar.

Keempat, memperhatikan struktur LKPD. Struktur LKPD meliputi enam komponen, yakni judul, petunjuk belajar (petunjuk peserta didik), kompetensi yang akan dicapai, informasi pendukung, tugas, dan langkah-langkah kerja, serta penilaian. Kelima, menyusun komik dengan menggunakan aplikasi comic life 2, Alasan peneliti menggunakan comic life 2 adalah karena aplikasi ini mudah digunakan terutama bagi pemula dan hasilnya cukup menarik. Selain itu, peneliti menggunakan program android yaitu momencam untuk membuat tokoh-tokoh yang berperan pada LKPD berbasis komik ini.

Keenam, pemilihan format LKPD yang disesuaikan dengan faktor-faktor yang telah dijelaskan pada tujuan pembelajaran. Format dipilih untuk mendesain LKPD sesuai dengan pendekatan CTL. Ketujuh, menentukan tahapan pembelajaran yang terdapat pada pengembangan LKPD berbasis komik pada pokok bahasan aritmatika sosial yakni 1) pemberian masalah awal untuk mengonstruksi pengetahuan, mengidentifikasi masalah; 2) menduga jawaban sementara (hipotesis) berdasarkan masalah; 3) mengumpulkan data (fakta dan informasi); 4) menguji hipotesis atau dugaan jawaban; 5) membuat kesimpulan; 6) mengerjakan soal penerapan. 
Tahap pengembangan (develop) bertujuan untuk menghasilkan LKPD final yang telah mengalami beberapa revisi berdasarkan masukan dari para ahli pada saat uji validitas dan data yang diperoleh dari uji coba terbatas. Kegiatan-kegiatan yang dilakukan pada tahap ini adalah validasi LKPD oleh ahli materi dan ahli desain, uji coba terbatas yaitu LKPD diberikan kepada peserta didik yang telah mempelajari materi aritmatika sosial, tahap pengembangan terakhir adala uji coba lapangan. LKPD yang baik memuat struktur LKPD secara umum yaitu 1) judul kegiatan, Tema, Sub Tema, Kelas, dan Semester, berisi topik kegiatan sesuai dengan KD dan identitas kelas; (2) tujuan, tujuan belajar sesuai dengan KD; 3) alat dan bahan, jika kegiatan belajar memerlukan alat dan bahan, maka dituliskan alat dan bahan yang diperlukan; 4) prosedur Kerja, berisi petunjuk kerja untuk peserta didik yang berfungsi mempermudah peserta didik melakukan kegiatan belajar; 5) tabel Data, berisi tabel di mana peserta didik dapat mencatat hasil pengamatan atau pengukuran. Untuk kegiatan yang tidak memerlukan data bisa diganti dengan tabel/kotak kosong yang dapat digunakan peserta didik untuk menulis, menggambar atau berhitung; 6) bahan diskusi, berisi pertanyaan-pertanyaan yang menuntun peserta didik melakukan analisis data dan melakukan konseptualisasi.

Tahap penyebaran (desseminate) merupakan tahap akhir dari penelitian dan pengembangan model Thiagarajan. Ada dua kegiatan yang dapat dilakukan pada tahap ini, yaitu sosialisasi produk hasil pengembangan pembelajaran dan penggunaan. Sosialisasi produk dapat dilakukan kepada praktisi pembelajaran diantaranya tenaga pengajar, guru, sekolah dan siswa. Tahap penyebaran dilakukan untuk menguji tingkat efektifitasnya dengan melakukan uji eksperimen produk terhadap objek pembelajaran atau membandingkan produk hasil pengembangan dengan produk yang lain. Kegiatan sosialisasi dan penggunaan dalam bentuk uji eksperimen pada tahap penyebaran adalah hasil modifikasi kegiatan yang mengadopsi dari prosedur penelitian dan pengembangan[16].

\section{HASIL DAN PEMBAHASAN}

Hasil penelitian pada tahap pendefinisian (define) meliputi tiga aspek yaitu analisis peserta didik, materi dan tugas. Berdasarkan hasil wawancara dengan beberapa guru matematika SMP/MTs di Kota Metro diperoleh karakteristik peserta didik memiliki kemampuan belajar matematika yang cukup homogen dan mampu menyelesaikan masalah secara berkelompok. Akan tetapi peserta didik terbiasa hanya menghafal rumus tanpa memahami konsep penggunaan rumus, sehingga sulit untuk menyelesaikan soal yang non rutin. Azizah [17] memaparkan rendahnya kemampuan pemecahan masalah matematika siswa kelas VII SMP TMI Lampung. Tes awal kemampuan pemecahan masalah matematika yang diberikan kepada siswa kelas VIID hasilnya menunjukkan bahwa dari 4 soal pemecahan masalah bangun datar yang diberikan, hasilnya hanya $6,7 \%$ siswa yang mencapai nilai 70 , sedangkan sisanya 93,3\% siswa belum mencapai KKM. Selain itu, peserta didik hanya mendengar penjelasan materi dari guru sehingga kurang aktif dalam proses pembelajaran.

Analisis materi difokuskan pada materi aritmatika sosial SMP. Berdasarkan hasil analisis materi dirumuskan beberapa indikator materi aritmatika sosial diantaranya membedakan harga satuan dan harga keseluruhan suatu barang, menghitung harga satuan dan harga keseluruhan suatu barang, menentukan besar harga jual dan harga beli dalam kegiatan ekonomi, menentukan besar untung dan rugi dalam kegiatan ekonomi, menghitung besar diskon dalam kegiatan ekonomi, melakukan perhitungan perdagangan yang melibatkan bruto, tara dan neto, menjelaskan bunga tabungan, menghitung bunga tabungan, menjelaskan pajak, menghitung pajak. 
Hasil dari analisis tugas meliputi Struktur isi LKPD mencakup enam komponen, yaitu judul, petunjuk belajar, komponen yang akan dicapai, informasi pendukung, tugas-tugas dan langkah-langkah kerja, serta penilaian. Jumlah LKPD sebanyak tujuh, artinya materi aritmatika sosial akan disusun dalam LKPD yang dapat digunakan untuk tujuh pertemuan.

Hasil yang diperoleh pada tahap perencanaan diantaranya penyusunan Format, LKPD dan tes. Pada tahap awal LKPD disusun dalam Draft 1 yang disajikan pada tabel 1.

\section{Tabel 1. Draft 1}

1. LKPD 1 (harga satuan $\&$ harga keseluruhan)

a. Membedakan harga satuan dan harga keseluruhan suatu barang.

b. Menghitung harga satuan dan harga keseluruhan suatu barang

1. LKPD 2 (harga jual \& harga beli)

a. Menentukan besar harga jual dan harga beli dalam kegiatan ekonomi.

2. LKPD 3 (untung \& rugi)

a. Menentukan besar untung dan rugi dalam kegiatan ekonomi.

3. LKPD 4 (diskon / potongan harga)

a. Menghitung besar diskon dalam kegiatan ekonomi.

4. LKPD 5 (bruto, tara \& neto)

a. Melakukan perhitungan perdagangan yang melibatkan bruto, tara dan neto

5. LKPD 6 (bunga tabungan)

a. Menjelaskan bunga tabungan

b. Menghitung bunga tabungan dan pajak

6. LKPD 7 (pajak)

a. Menjelaskan pajak

b. Menghitung pajak

Setelah penyusunan draft 1 selesai, maka pada tahap pengembangan LKPD diuji validitas. Uji validitas yang digunakan adalah uji validitas ahli. Uji ahli dilakukan oleh ahli materi dan ahli desain. Ahli materi dan ahli desain diberikan angket dan produk hasil pengembangan LKPD berbasis komik. Pengisian angket disesuaikan dengan pengamatan ahli terhadap produk yang dihasilkan. Hasil yang diperoleh dari ahli materi sebesar 4,31 dengan kategori baik dan hasil yang diperoleh dari ahli desain sebesar 4,24 dengan kategori baik berdasarkan kriteria penilaian pada tabel 2.

Tabel 2. Kriteria Validasi Desain dan Materi

\begin{tabular}{ll}
\hline Skala & Kriteria \\
\hline $0,1-1,0$ & tidak valid \\
\hline $1,1-2,0$ & kurang valid \\
\hline $2,1-3,0$ & Cukup \\
\hline $3,1-4,0$ & Valid \\
\hline $4,1-5,0$ & Sangat valid \\
\hline
\end{tabular}

Setelah draft 1 diuji oleh ahli, dilakukan revisi draft 1 . Saran yang diberikan oleh ahli materi berkaitan dengan alokasi waktu yang kurang sesuai dengan karakteristik peserta didik dan materi yang diberikan. Selain itu ahli materi menyarankan untuk memperbaiki kolom kesimpulan agar kesimpulan yang dibuat oleh peserta didik tidak meluas. Contoh revisi dapat dilihat pada tabel 1 dan tabel 2. 
Numerical: Jurnal Matematika dan Pendidikan Matematika, Vol. 1 No. 2 Desember 2017, 63-72 Isnaini Nur Azizah

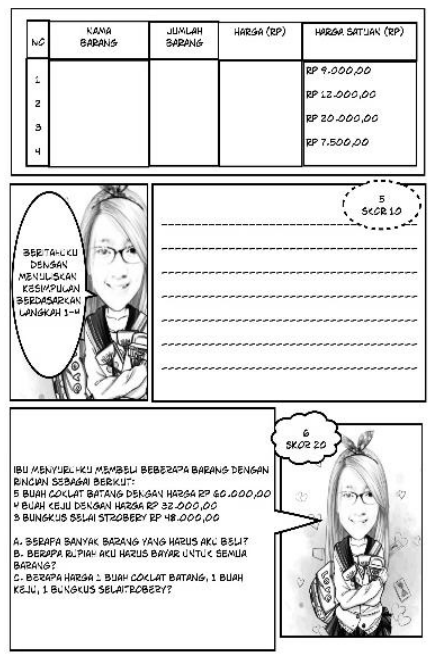

Gambar 1. LKPD 1 Sebelum Direvisi

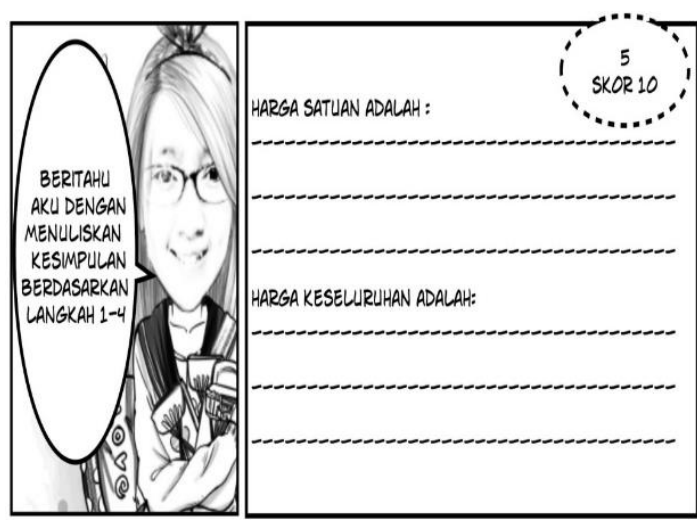

Gambar 2. LKPD 1 Setelah Direvisi

Adapun saran yang diberikan oleh ahli desain adalah hendaknya menuliskan materi yang akan di pelajari pada cover agar peserta didik mengetahui materi apa yang sedang mereka pelajari. Selain itu, validator juga menyarankan untuk menulis judul secara lebih khusus di setiap LKPD dengan jelas. Judul tidak harus ditulis lengkap. Judul bisa menggunakan kata-kata yang berkaitan erat dengan materi yang dipelajari pada LKPD. Validator juga menyarankan untuk menambahkan kolom pengenalan tokoh yang ada pada LKPD berbasis komik supaya sebelum membaca komik peserta didik sudah mengetahui tokoh-tokoh yang disajikan yang memudahkan peserta didik dalam mengikuti alur cerita yang dituangkan dalam LKPD berbasis komik. Contoh revisi yang telah dilakukan dapat dilihat pada gambar 3,4 dan 5 . 
Numerical: Jurnal Matematika dan Pendidikan Matematika, Vol. 1 No. 2 Desember 2017, 63-72 Isnaini Nur Azizah

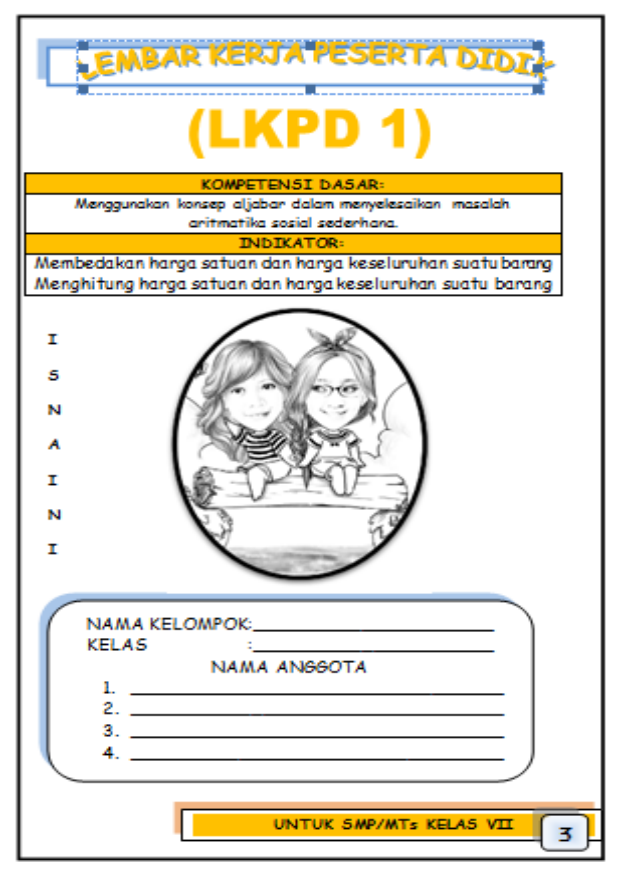

Gambar 3. LKPD 1 Sebelum Direvisi

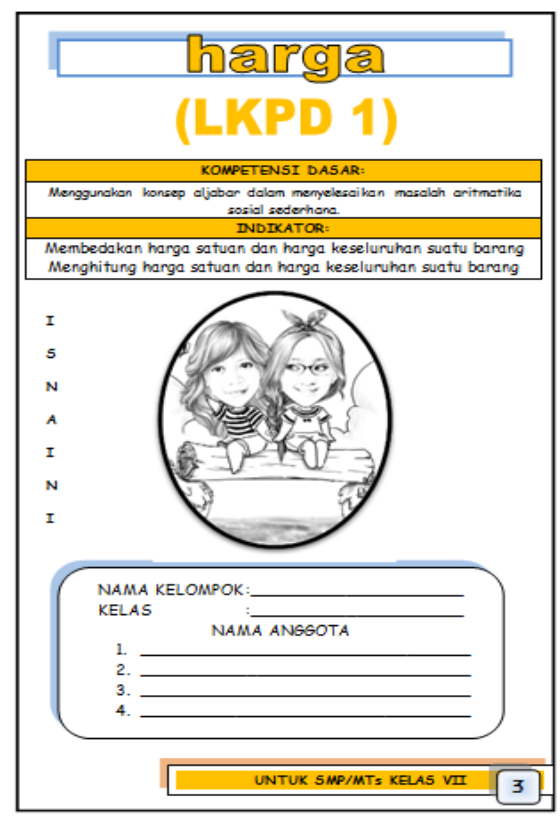

Gambar 4. LKPD 1 Sesudah Direvisi 


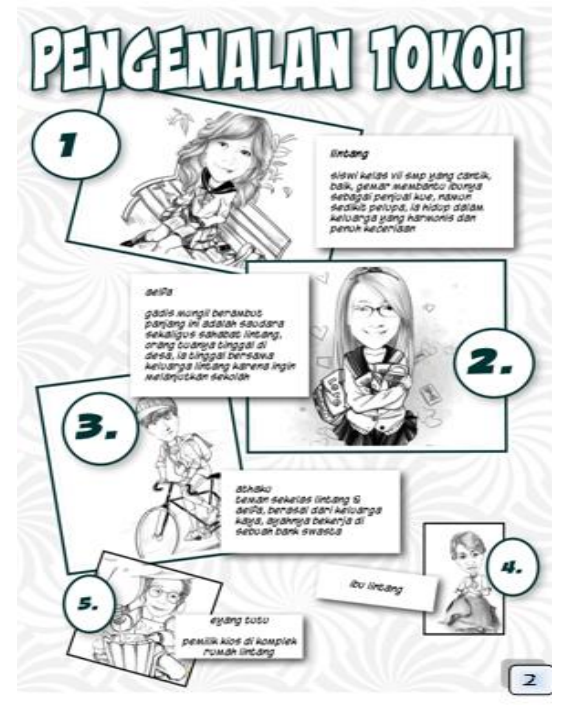

Gambar 5. Pengenalan Tokoh

Setelah draft 1 selesai direvisi menjadi draft 2. Draft 2 diuji coba terbatas kepada enam peserta didik kelas IX yang telah mempelajari materi aritmatika sosial. Selanjutnya peserta didik dibagi menjadi dua kelompok. Skor rata-rata pengerjaan LKPD keseluruhan adalah 86,5. Revisi draft 2 dilakukan berdasarkan hasil uji coba terbatas, maka ditemukan bagian yang perlu direvisi terdapat pada LKPD 3 tahapan keempat yaitu menambahkan kolom barang yang dibeli.

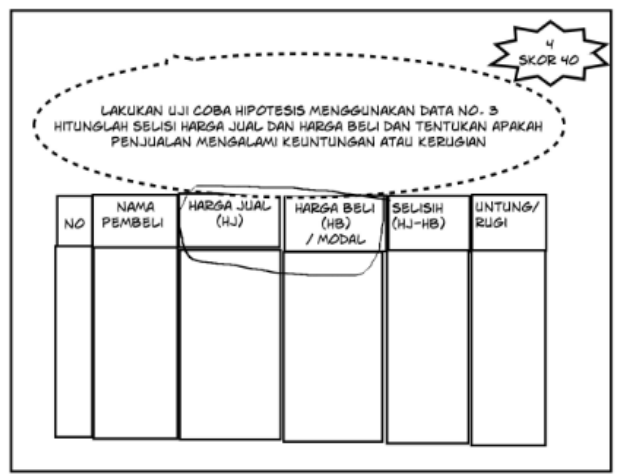

Gambar 6. LKPD 3 Sebelum Direfisi 


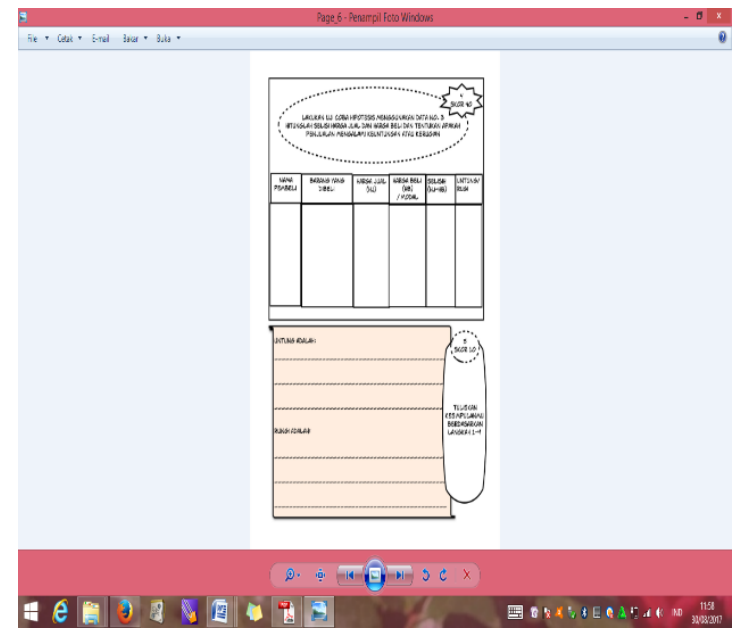

Gambar 7. LKPD 3 Setelah Direvisi

Hasil uji coba terbatas digunakan untuk merevisi menjadi draft 3. Kemudian dilakukan uji coba lapangan untuk draft 3 kepada peserta didik. Akan tetapi pada penelitian ini hanya dibatasi pada hasil yang diperoleh pada draft 3. Pada penelitian dan pengembangan ( $\&$ \&) semakin banyak uji coba yang dilakukan maka produk yang dihasilkan akan semakin mendekati sempurna sehingga efektif dan siap untuk dipublikasikan.

\section{SIMPULAN DAN SARAN}

Simpulan yang diperoleh sebagai hasil dari pengembangan LKPD berbasis komik yang diterapkan pada materi aritmatika sosial untuk level berpikir menengah ke bawah. Struktur penyajian materi dalam pengembangan LKPD berbasis komik dibagi menjadi tujuh pertemuan yang memuat unsur-unsur diantaranya membedakan dan menghitung harga satuan dan harga keseluruhan, menentukan besar harga jual dan harga beli, menentukan besar untung dan rugi, menghitung besar diskon, melakukan perhitungan perdagangan yang melibatkan bruto, tara dan neto, menghitung bunga tabungan dan menghitung pajak.

Struktur isi LKPD berbasis komik mencakup enam komponen yaitu judul, petunjuk belajar, komponen yang akan dicapai, informasi pendukung, tugas-tugas dan langkah-langkah kerja, serta penilaian. Masalah yang diberikan dalam LKPD berbasis komik dikerjakan secara berkelompok dan soal penerapan yang diberikan adalah soal cerita yang melatih peserta didik memecahkan masalah secara sistematis. Artinya soal tersebut mampu memunculkan kemampuan pemecahan masalah peserta didik.

Berdasarkan hasil penelitian dan pengembangan, disarankan oleh penulis sekiranya peneliti lain yang ingin melakukan penelitian sejenis dapat mengembangkan penelitian lanjutan mengenai LKPD berbasis komik pada materi aritmatika sosial hendaknya mengujicobakan kembali LKPD dalam jangka waktu yang lebih lama dan dilakukan lebih dari satu kali uji coba.

\section{DAFTAR PUSTAKA}

[1] Widjajanti, Endang, Kualitas Lembar Kerja Siswa. Yogyakarta: UNY, 2008.

[2] Depdiknas, Panduan Pengembangan Pembelajaran IPA Terpadu Sekolab Menengah Pertama dan Madrasah Tsanawiyah. Jakarta: Puskur, 2008.

[3] Kaymakci, Selahattin, "Review of studies of worksheets in Turkey," J US-China Educ. Rev. 
[4] Prastowo, Andi, Panduan Kreatif Membuat Baban Ajar Inovatif. Yogjakarta: Diva Press, 2011.

[5] Widyawati, S., "Pengaruh Kemampuan Koneksi Matematis Siswa terhadap Prestasi Belajar Matematika Ditinjau dari Gaya Belajar pada Materi Bangun Ruang Sisi Datar Siswa Kelas IX SMP di Kota Metro," J. Iqra, vol. 1, no. 1, pp. 47-67, 2016.

[6] Kemendikbud, "Peraturan Mentri Pendidikan dan Kebudayaan Nomor 8 tahun 2016 tentang Buku yang Digunakan oleh Satuan Pendidikan.” .

[7] Loviana, Selvi, "Pengembangan LKPD dengan Menggunakan Model Problem Based Learning untuk Memfasilitasi Kemampuan Komunikasi Dan Disposisi Komunikasi (Studi Pada Siswa Kelas VIII Semester Ganjil Smp Negeri 9 Metro Tahun Pelajaran 2015/2016)," Tesis Universitas Lampung, Lampung, 2016.

[8] Sari, Esti Swatika, "Komik Sebagai Wahana Pendukung Proses Pendidikan Anak," Diksi, vol. 8, no. 9, 2011.

[9] Ningsih, E. F., "Proses Berpikir Mahasiswa dalam Pemecahan Masalah Aplikasi Integral Ditinjau dari Kecemasan Belajar Matematika (Math Anxiety)," Iqra Educ. J., vol. 1, no. 2, pp. 191-217, 2017.

[10] Woe Titi Cahyani, Restilawati, "Pengembangan Mathematical Comic dengan Metode PQ4R untuk Mengembangkan Komunikasi Matematika dan Disposisi Matematika Kelas VIII," Universitas Lampung, Lampung, 2016.

[11] Sudjana, Nana and Rivai, Ahmad, Media Pengajaran. Bandung: Sinar Baru, 2002.

[12]Y. Setyawati and S. Hermawan, "Persepsi Pemilik Dan Pengetahuan Akuntansi Pelaku Usaha Mikro Kecil Dan Menengah (UMKM) Atas Penyusunan Laporan Keuangan," Ris. Akunt. Dan Keuang. Indones., vol. 3, no. 2, 2018.

[13] Sugiyono, Metode Penelitian Pendidikan (Pendekatan Kuantitatif, Kualitatif, dan R\&D). Bandung: Alfabeta, 2013.

[14] Thiagarajan, S., Semmel, D.S., and Semmel, M.I., Instructional Development for Training Teachers of Exceptional Children: A Sourcebook. Indiana: Indiana University, 1974.

[15] Trianto, Mendesain Model Pembelajaran Inovatif-Progresif: Konsep, Landasan, dan Implementasinya Pada Kurikulum Tingkat Satuan Pendidikan (KTSP). Jakarta: Kencana Prenada Media Group, 2010.

[16] Borg, Walter R., Gall, Meredith D., and Gall, Joyce P., Educational Research an Introdution Seventh Edition. Longman: United States of America, 2003.

[17] Azizah, Isnaini Nur, "Pengaruh Model Pembelajaran Kooperatif Tipe Rotating Trio Excgange Terhadap Kemampuan Pemecahan Masalah Matematika Siswa di SMP TMI Lampung," Repository UIN Jakarta, Jakarta, 2013. 